\title{
Analysis of well logs for the detection of coal seams - A case study from Rajbar block of Auranga coalfield, Jharkhand, India.
}

\author{
Srinaiah. J* \\ CSIR-National Geophysical Research Institute, Hyderabad-500007. \\ *srinaiah.geophysics@gmail.com \\ DOI: $10.31364 /$ SCIRJ/V7.i11.2019.P1119720 \\ http://dx.doi.org/10.31364/SCIRJ/v7.i11.2019.P1119720
}

\begin{abstract}
Geophysical well logging survey was carried in nine different boreholes in the Rajbar block of Auranga coalfield in the Damodar valley area of Jharkhand, India in order to delineate a number of coal seams, their depth, thickness and lithology. I used a conventional set of logs consisting of Density, Gamma-ray, Single point resistance and Resistivity for the delineation of several unknown coal seams. Lithological interpretation was carried out using Ward's method of hierarchical cluster analysis to decipher the variation of litho-facies of each borehole. Also, agglomerative clustering was used to assign a distinct lithology for each unique interval in the borehole. I found that the interpreted physical properties from each borehole are in good agreement with the range of physical properties obtained from core samples analysed in the laboratory which enhance the reliability of interpreted litho-logs.
\end{abstract}

Keywords: Coal seams, well logs, cluster analysis, physical properties, core samples.

\section{Introduction}

Well log data are being widely used to detect thin coal seams due to the inherent advantage of high-resolution information $(>10 \mathrm{KHz})$ and its cost effectiveness, in comparison to core drilling. Well-logs recorded at 1 inch equal to 10 feet scale, which is a standard practice in coal exploration, that can resolve coal seams as thin as 0.5 feet. A recent development, known as slim hole $(<$ 3-inch diameter probes) logging technology, can in fact provide geophysical logs for interpretation of coal depositional environment in an efficient and detailed manner (Jeffery et al., 1982). The conventional well-logs such as density, gamma-ray, single point resistance and resistivity are in vogue for identification of coal seams, variation of their thickness and also lateral correlations. Apart from detection, the parameters that describe the quality of coal such as ash content, volatile matter, specific energy, presence of radioactive minerals (such as pyrite) in coal in addition to economic and engineering parameters, can also be predicted with the combination of sonic, neutron porosity and induced polarization logs (Kowalski and Fertl, 1976; Ghosh, 2016; Zhou et al, 2016). Besides, Caliper log is also used to know the borehole rugosity, which affects the readings recorded by other logs. Further, Spontaneous Potential (SP) log has also been used to distinguish permeable beds from the shale and coal layers. In fact, the lithological layers in a coal exploratory bore well probed by conventional logs can be interpreted by incorporating the 
data obtained from core sample measurements and drillers log information(Jeffery et al., 1980). In the present study, I make an attempt to interpret the conventional logs in order to detect a number of coal seams, their lithology and thickness in nine different bore wells in Rajbar coal black of Auranga coal field.

\section{Geology of the study area}

The Rajbar coal block, covering an area of $17 \mathrm{~km}^{2}$ and bounded between latitudes $23^{\circ} 45^{\prime} 18.8^{\prime \prime}$ to $23^{0} 47^{\prime} 59.0^{\prime \prime} \mathrm{N}$ and longitudes $84^{0} 37^{\prime} 47.4^{\prime \prime}$ to $84^{0} 40^{\prime} 51.6^{\prime \prime} \mathrm{E}$, is an integral part of Auranga coal field in the Jharkhand State of India. The location map of the study area is shown in Fig. 1. This particular region is bestowed with the presence of abundant mineral resources like, bauxite, coal, iron, pyrite, limestone, copper, china clay, fine clay, graphite, soapstone, silica sand and quartz sand(Dutt and Datta, 2000) and thus occupies an important position in the country in terms of coal reserve The Auranga coalfield is the eastern most member of the Koel Valley group of coalfields in Latehar District. The Rajbar coal black is the largest in comparison to the several other blocks like Jagaldagga, Gowa, Rajbar, Sabanu, and Banhardi, identified in the Auranga Coalfield( Raju et al, 2015; Rizvi, 1972). The stratigraphy of the Auranga Coalfield as reported by Rao, 1987 is presented in Table 1, which indicates that the most coal baring formations belong to lower Gondwana group, which houses almost $99 \%$ of coal resources in the country. The lower Gondwana sequence is made up of variouscoal bearing formations viz., Karhabari, Barakar and Raniganj. Almost over 90\% of coal reserves are located in Barakar formation which includes the identified coal seams too. The coal seams at this block are of non-cocking type and contain a medium quantity of moisture, medium to high amount of volatile matter besides high amount of ash ( Raju et al, 2015).

\section{Methodology}

Well logging survey was carried out in Rajbar coal black of Auranga coal field for delineation of coal seams in the area (Fig.1). Nine bore holes were drilled at various locations, as shown in Fig. 2 and in each bore hole, caliper, density, gamma-ray, short normal resistivity, long normal resistivity, single point resistance and self-potential logs were recorded for identifying coal and non-coal litho-facies, their depth and thickness in each borehole. Interpretation of all the aforesaid logs particularly density, gamma-ray, resistivity, and single point resistance logs were carried out for classifying the number of coal seams, their lithology and variation of their thickness in each borehole. A depth interval of distinct well logs characteristics is assigned to a particular zone using Ward's method of hierarchical cluster analysis, which involves an agglomerative clustering procedure. Initially, a data point at each depth sample is considered as a distinct zone. Thereafter, an iterative procedure commences to merge two zones for generating a composite zone, which is considered as a single zone in the next iteration. The iterative procedure for generating composite zones consists of ' $n(n+1) / 2$ ' possible pairs to be merged for the generation of ' $n$ ' zones, out of the ' $n+1$ 'available numbers of zones. Among all possible ways of merging two zones, the pair to be merged is chosen that minimizes the sum of 
squared distances between the points and the centroids of their respective zones (Wilks, 2011). Since the zonation process considers minimum distance between the points and the centroid of the zone, it also assures that the zones are demarcated by strong deflection of log readings, which in general, represent boundaries of litho-facies. Each zone is assigned a distinct lithology on the basis of the rock physical properties. The interpretation process is continued until a satisfactory number of lithological zones have been generated. The number of lithological zones are decided based on the prior knowledge from cored wells and visual interpretation of well logs. The bulk density and gamma-ray reading range of various lithologies as obtained from core measurements are presented in Table 3. The interpretation of logs from the study area has shown following well logging characteristics:

The bulk density of coal is found to be the lowest as compared to other lithologies. The readings of gamma-ray of coal is also observed to be lower; however, it is overlapping with that of sandstone. Further, the resistivity of pure coal is higher than that of shale and also overlapping with that of sandstone, though shale partings have significantly reduced it. The carb-shale intervals have still lower resistivity range, which overlaps with that of shale. It may be mentioned here that Self Potential (SP) log is featureless in the study area, thus, no correlation could be established between the SP deflection and the lithology. The caliper log shows almost remains constant indicating that there are no caved zones. Thus, the readings of other logs were not affected by wellbore rugosity in all the nine studied bore wells.

\section{Results and discussion}

The lithology physical properties of SP, caliper, resistivity, single point resistance, gamma-ray and density etc in all nine boreholes of the study area are shown in Figs- 3 to Fig. 11. The density, gamma-ray, single point resistance, short normal and long normal resistance logs have shown a consistent correlation of well logs characteristics of coal seams in all the boreholes. Ten seams named as I to X from bottom to top are identified in each borehole. The depth to the top, bottom, thickness, and lithology of every seam in each borehole are presented in Table-2. As observed from the Tables, some of the seams represent carb-shale and shaly-coal lithology, which could be due to poor quality of coalification process.

The cross-plots (Fig. 12 and Fig. 13) between gamma-ray and density readings of various lithologies interpreted at bore-hole 45, implies that the physical property range of interpreted litho-facies is in good agreement with the physical property range obtained from core sample analysis in the laboratory. One can also observe a correlation of gamma-ray and density readings of interpreted litho-facies on the litho-logs at different boreholes reasonably with that of the measured values in Tables 2 substantiating the interpreted litho-log to be reliable.

However, the resistivity and density logs have shown abnormal readings in the zones covered by the casing and therefore, casing zone was not interpreted. It may be noted that the casing zone, did not affect the gamma-ray reading, which is clear from in all 
the boreholes. Thus, it may be found that the gamma-ray log can act as an effective and more useful tool for interpretation of very shallow seams, which if present are generally masked by the casing.

\section{Conclusion}

I have made an attempt to interpret conventional logs recorded in the Rajbar coal block of Auranga coal field which resulted the identification of ten coal seams, their depth, thickness and lithology. A fairly good correlation is found between the physical property range of the interpreted litho-facies with that of core sample measurements ensuring the reliability of the interpreted litho-logs. It may be noted that even in the absence of composite logs, a reliable interpretation of coal-seams their depth, thickness and lithology can be carried out using conventional logs. Further, out of the ten seams identified the seams III, II and I are found to be deeper than $200 \mathrm{~m}$ and are very thin. For such deeper and thinner seams, underground mining can be an economic, cleaner and environmental friendly approach.

\section{Acknowledgments}

The author expresses his sincere gratitude to the Department of Mines \& Geology, Ranchi. Sincere thanks to Sri. G. Jawahar, Director (Sel. Gr.), Retd. Geophysics at Geological Survey of India, Training Institute, Hyderabad for his great help to carry out the study and to Sri. M. A. Samad, GM- Geology Division, APC INDU JV GROUP, Hyderabad, for his support. The author is also thankful to Dr. V. Uma for her valuable suggestions and support.

\section{References}

Raju Doddi, Santhosh kumar.S, Muralidhar.M (2015). Coal Seam Delineation and Their

Proximate Analysis in North and Northeastern Parts of Auranga Coal Field,

Jharkhand, India. Internationaljournal of scientific research, 4(5), 2277 - 8179.

Dutt and Datta. (2000). Dutt, A.B and Datta, R.K (2000) Indian coal resources spectrum,Proc. Sem on New Challenges for Indian Coal. Coalresources of India.Mem. Geol. Survey of India, 10-13.

Ghosh, S., Chatterjee, R., \& Shanker, P. (2016). Estimation of ash, moisture content and detection of coal lithofacies from well logs using regression and artificial neural network modeling. Fuel, 177, 279-287.

Daniels, J. J., \& Scott, J. H. (1980). Computer-assisted interpretation of geophysical well logs in a coal depositional environment, Illinois Basin, Kentucky.

Kowalski, John, and Fertl, W.H., (1976). Application of geophysical well logging to coal mining operation: Houston, Tex., Dresser Atlas, Technical Memorandum, v.7, no. $8,11 \mathrm{p}$.

Zhou, B., \& O'Brien, G. (2016). Improving coal quality estimation through multiple 
geophysical log analysis. International Journal of Coal Geology, 167, 75-92.

Daniels, J. J., \& Scott, J. H. (1982). Automated lithological interpretation from geophysical well logs in a coal depositional environment, Carbon County, Wyoming.

In Proceedings, Fifth Symposium on the Geology of Rocky Mountain Coal: Utah

Geological and Mineral Survey Bulletin (Vol. 118, pp. 220-232).

Weltz, L. S. (1976, January). Log Evaluation of Sub-Bituminous Coals in Magallanes-Chile. In SPWLA 17th Annual Logging Symposium. Society of Petro physicists and Well-Log Analysts.

Wilks, D. S. (2011). Cluster analysis. In International geophysics (Vol. 100, pp. 603-616).

Academic press.

\section{Figures}

Fig. 1: Location map of the study area.

Fig. 2: The location map of the boreholes used in the study.

Fig. 3: The geophysical well logs and the lithology of bore-hole number 28 .

Fig. 4: The geophysical well logs and the litholog of bore-hole number 32.

Fig. 5: The geophysical well logs and the litholog of bore-hole number 36 .

Fig. 6: The geophysical well logs and the litholog of bore-hole number 37 .

Fig. 7: The geophysical well logs and the litholog of bore-hole number 45 .

Fig. 8: The geophysical well logs and the litholog of bore-hole number 46 .

Fig. 9: The geophysical well logs and the litholog of bore-hole number 53.

Fig. 10: The geophysical well logs and the litholog of bore-hole number 62 .

Fig. 11: The geophysical well logs and the litholog of bore-hole number 68 .

Fig. 12: The cross plots between Gamma-ray and density readings of shaly-coal and coal.

Fig. 13: The cross plots between Gamma-ray and density readings of sandstone and shale.

\section{Tables}

Table 1. Generalized stratigraphic section of Auranga coalfield (Rao, 1987).

Table -2: Coal seams depth range and thickness in bore-hole- 28, 32, 36,37,45,46,53,62,68.

Table-3: Characteristics of Geophysical well logs in the study area 


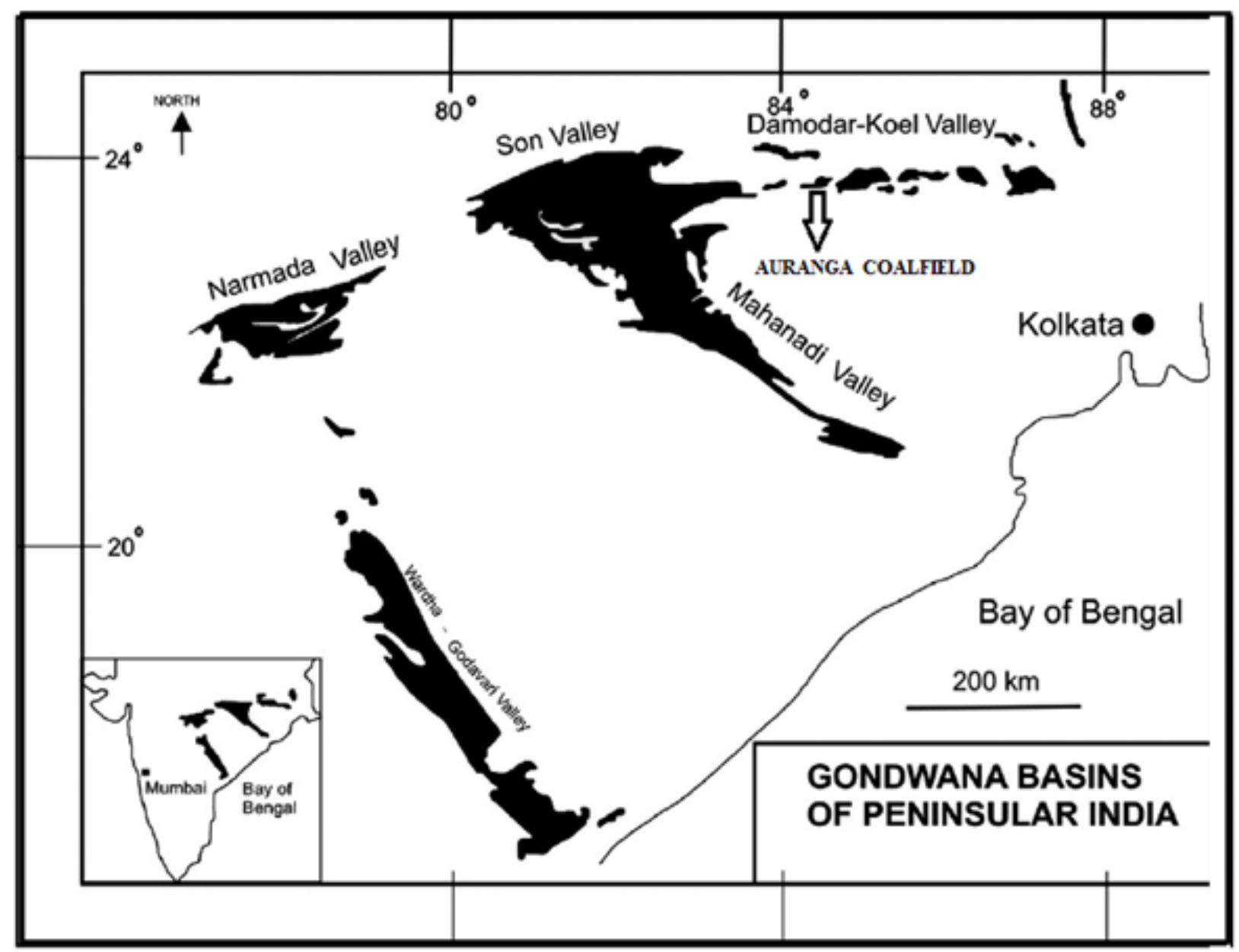

Fig. 5: Location map of the study area. 


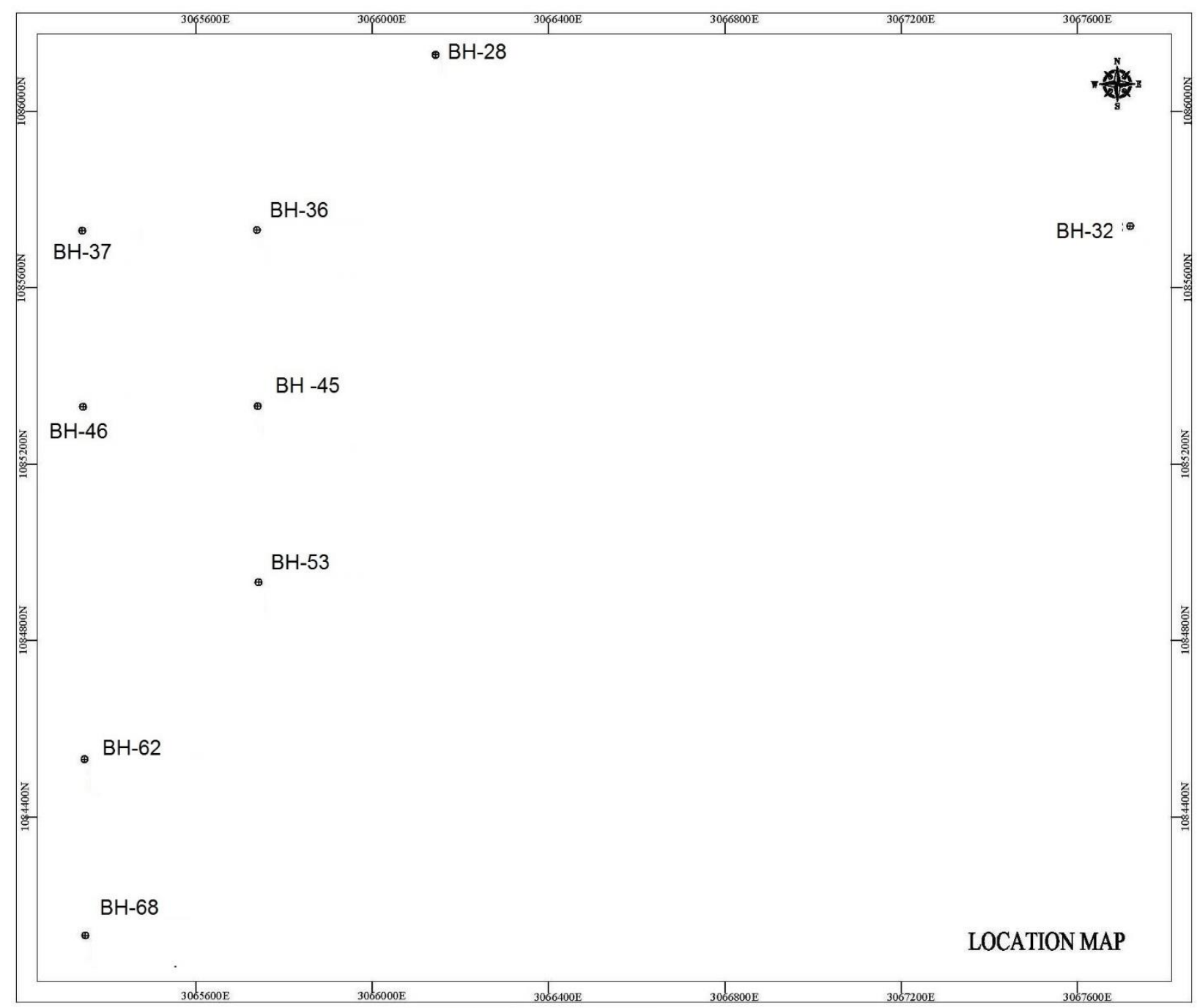

Fig. 6: The location map of the boreholes used in the study. 


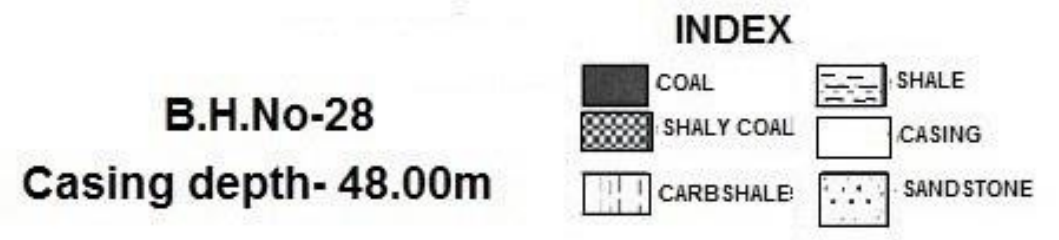

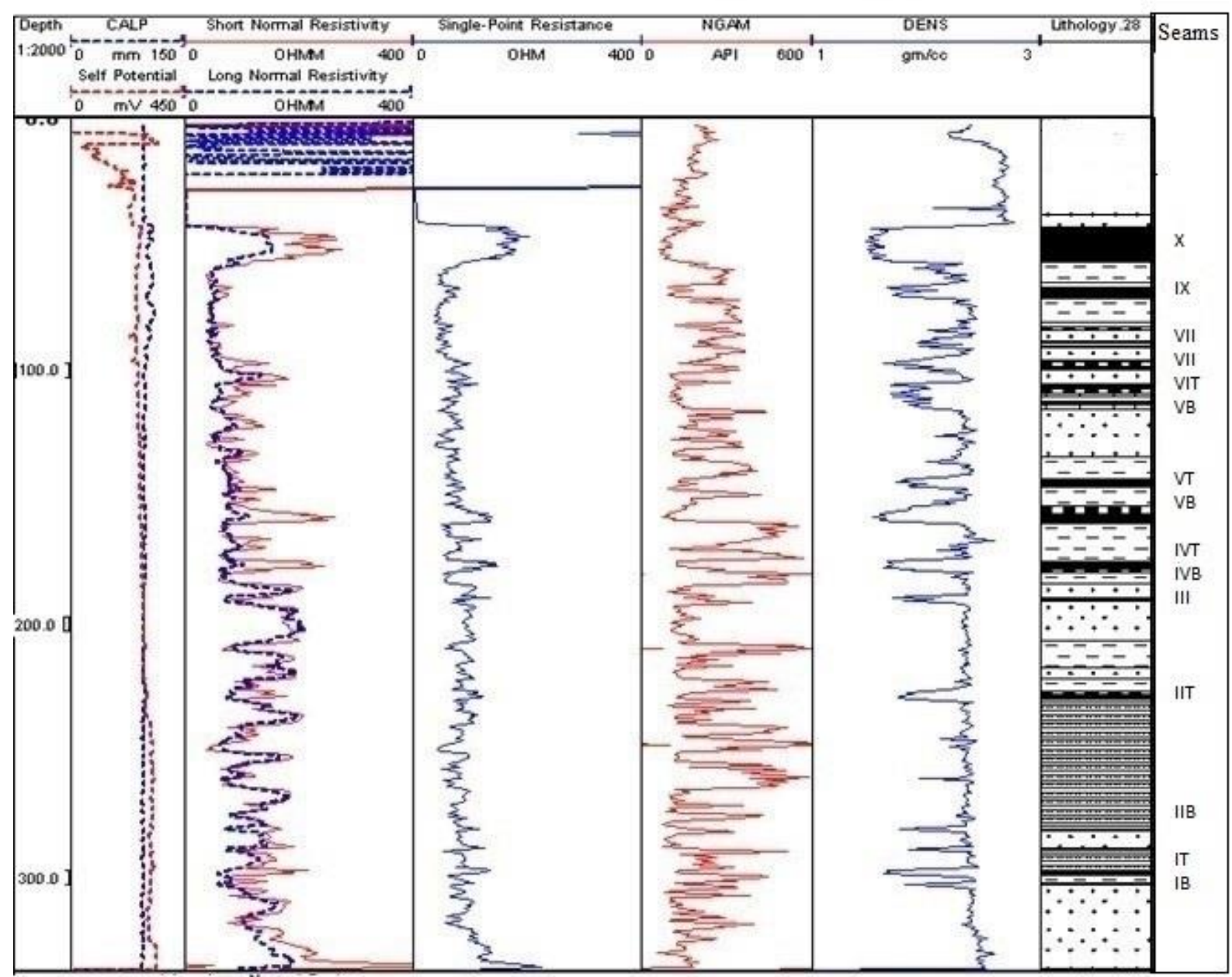


B.H.NO-32

Casing depth $-54.00 \mathrm{~m}$

\section{INDEX}

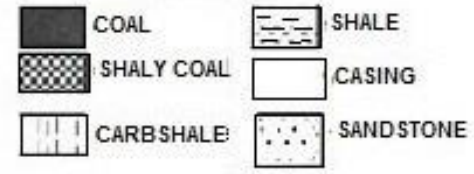

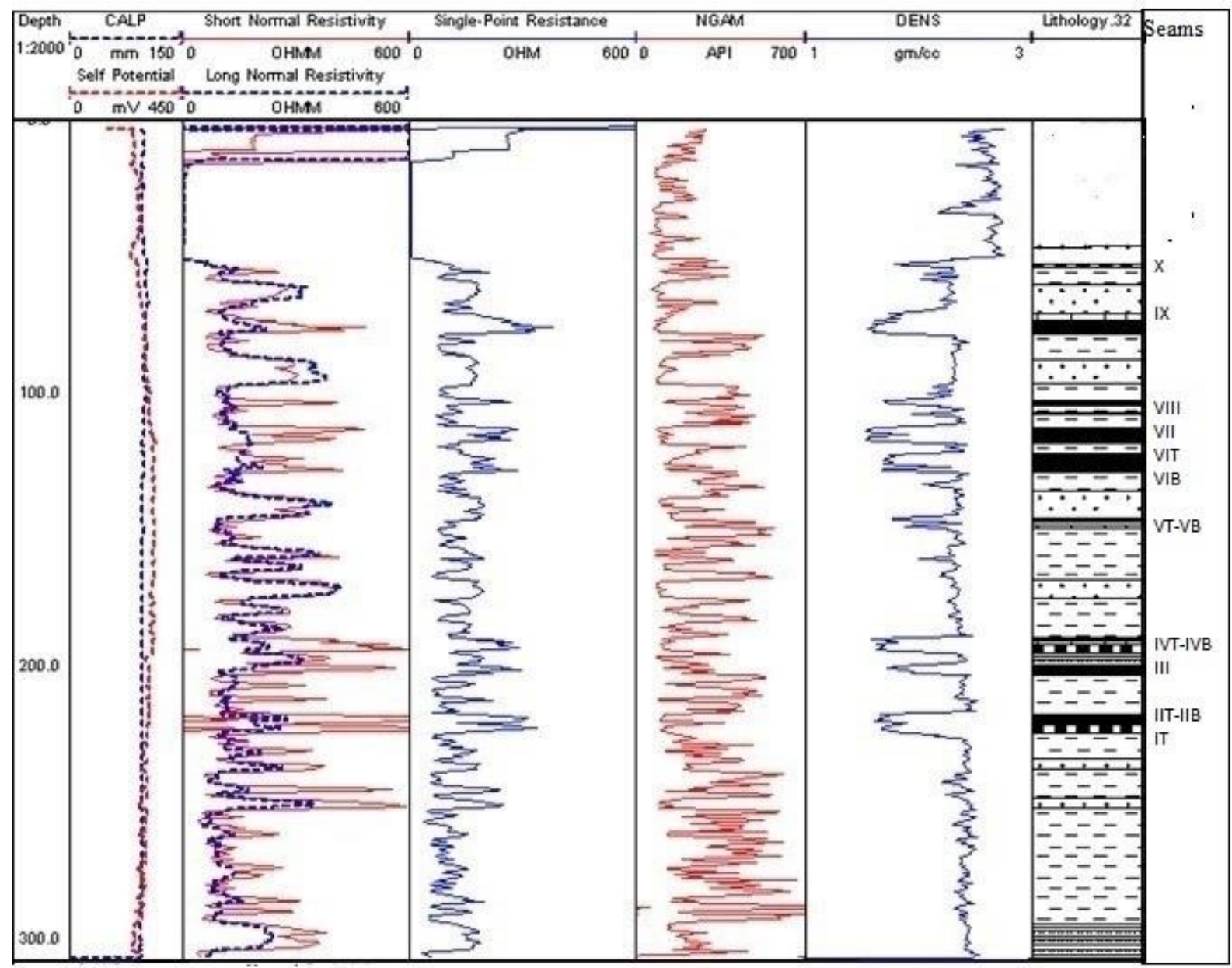



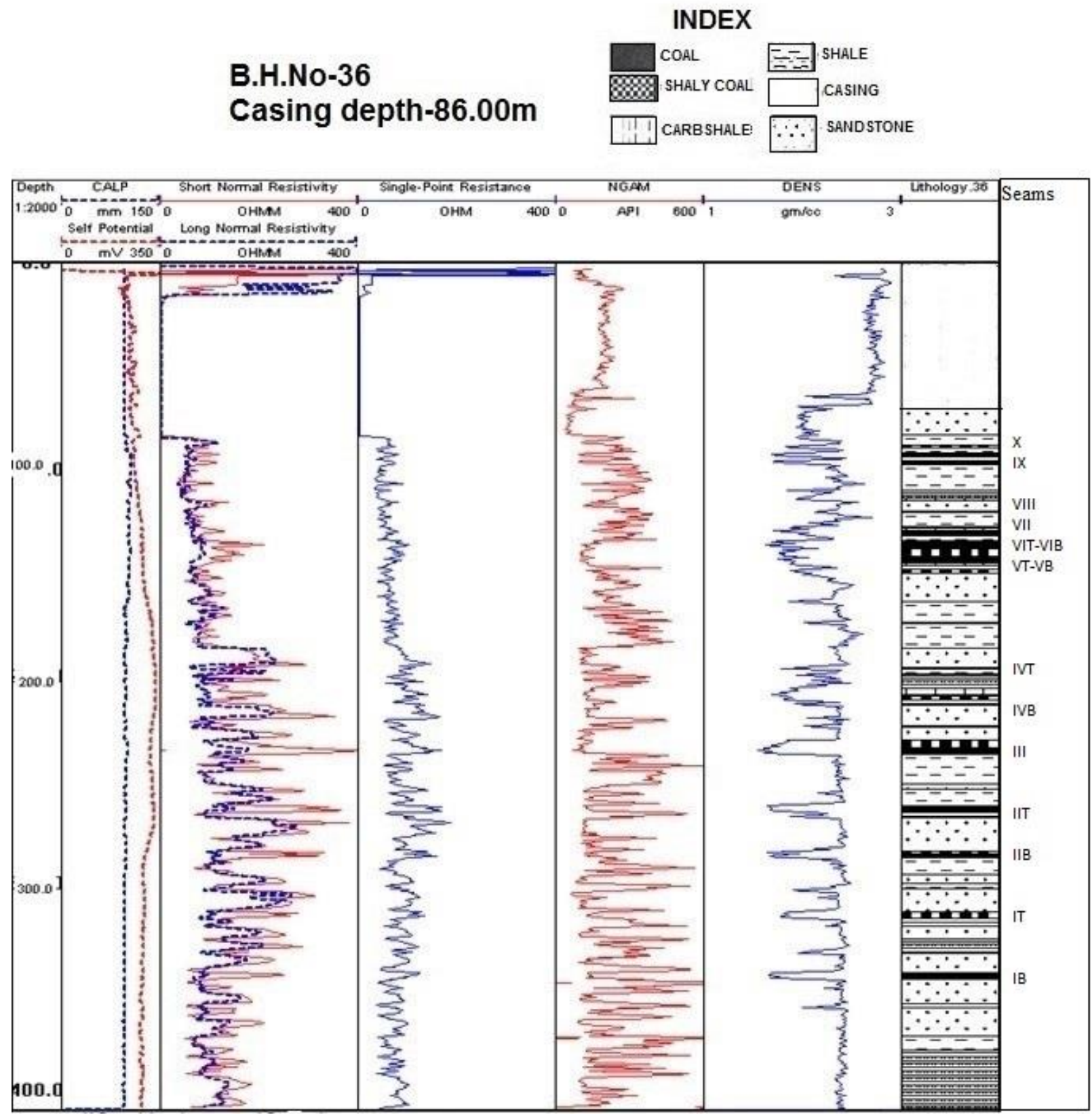


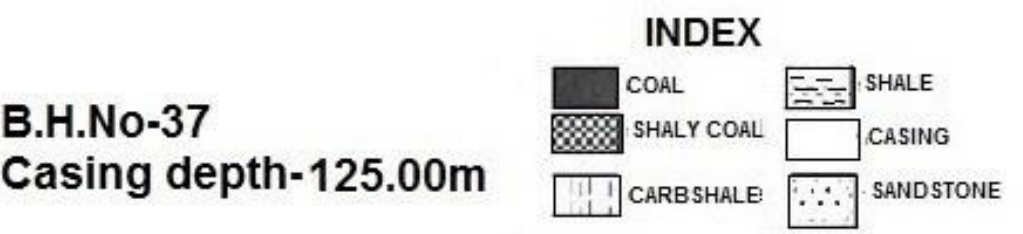

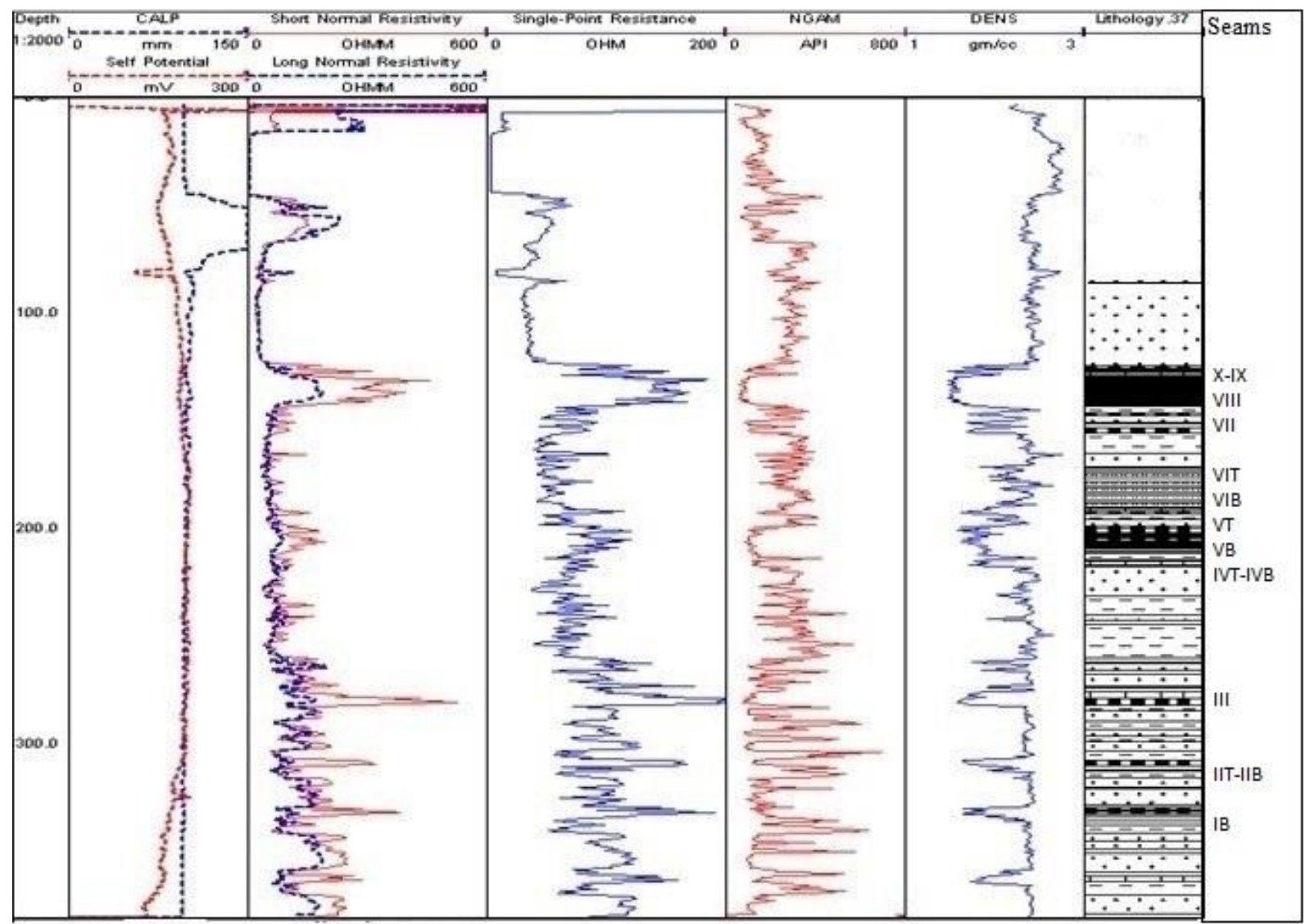


B.H.No-45 Casing depth-120.00m

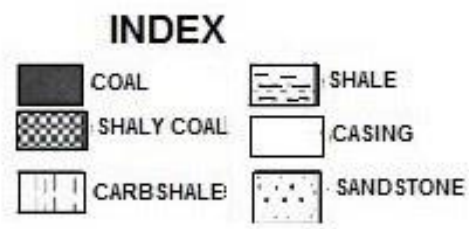

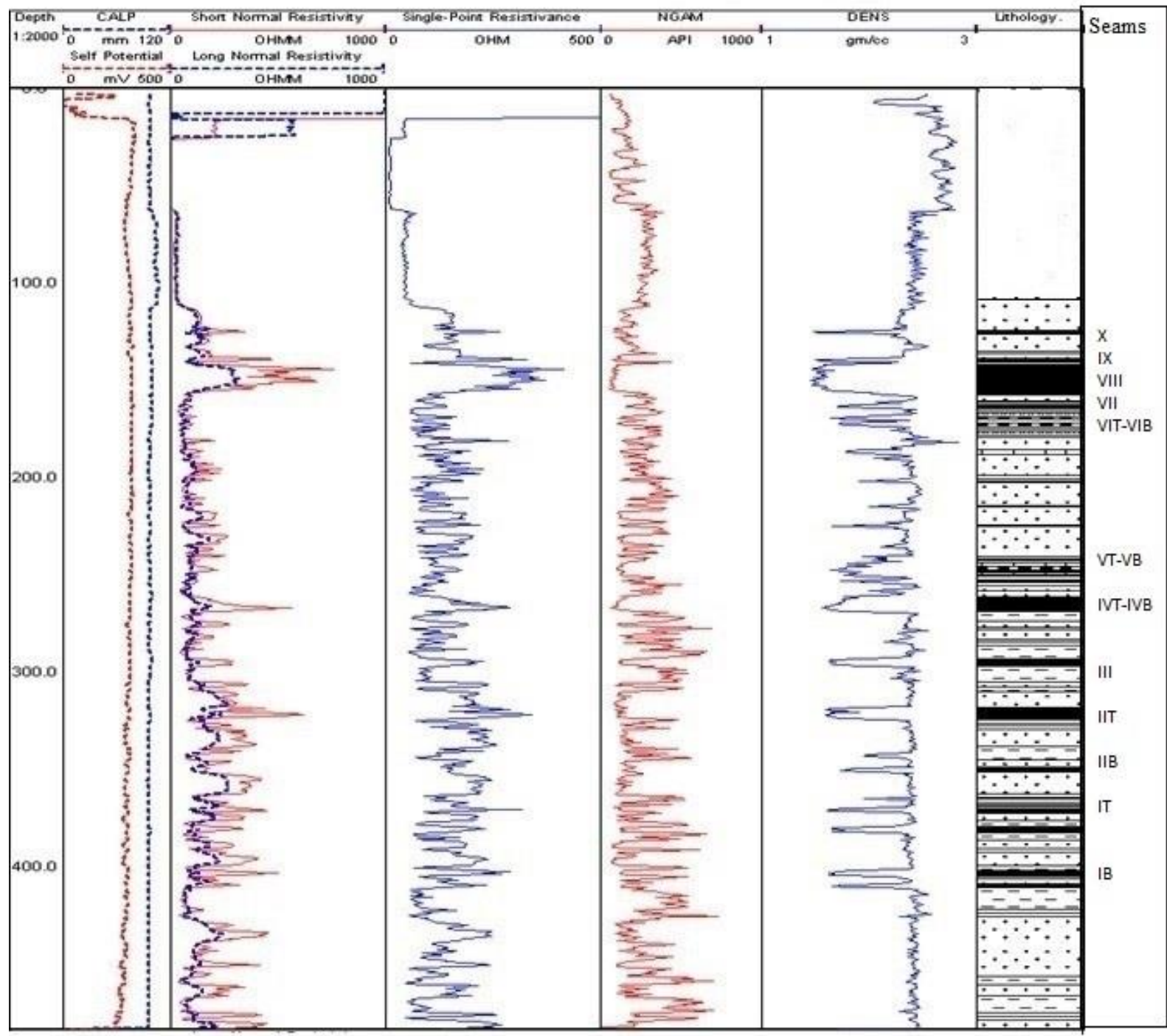




\section{B.H.No-46 Casing depth-66.00m}

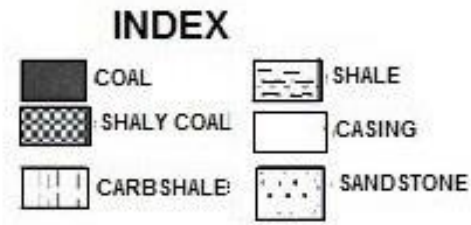

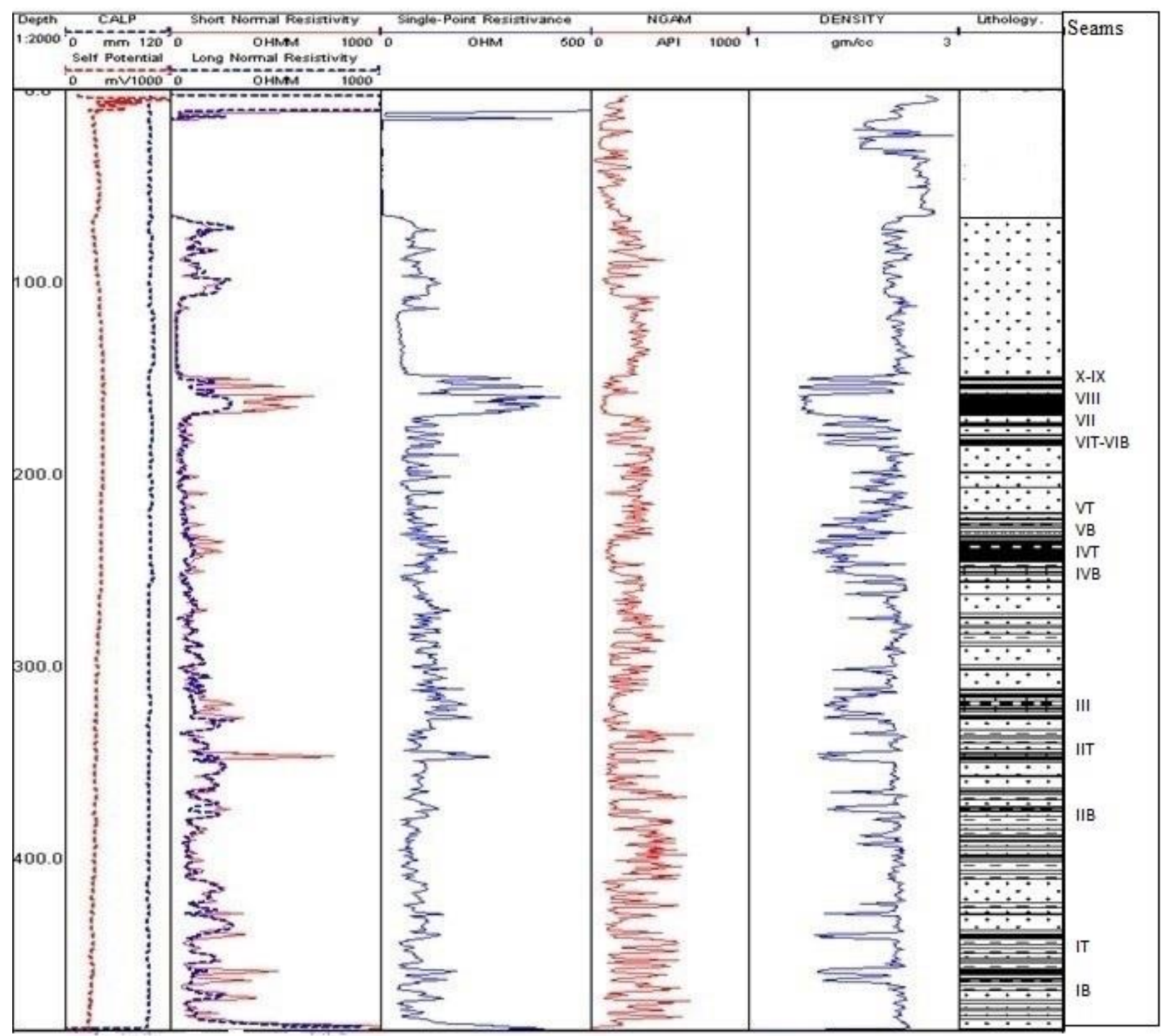




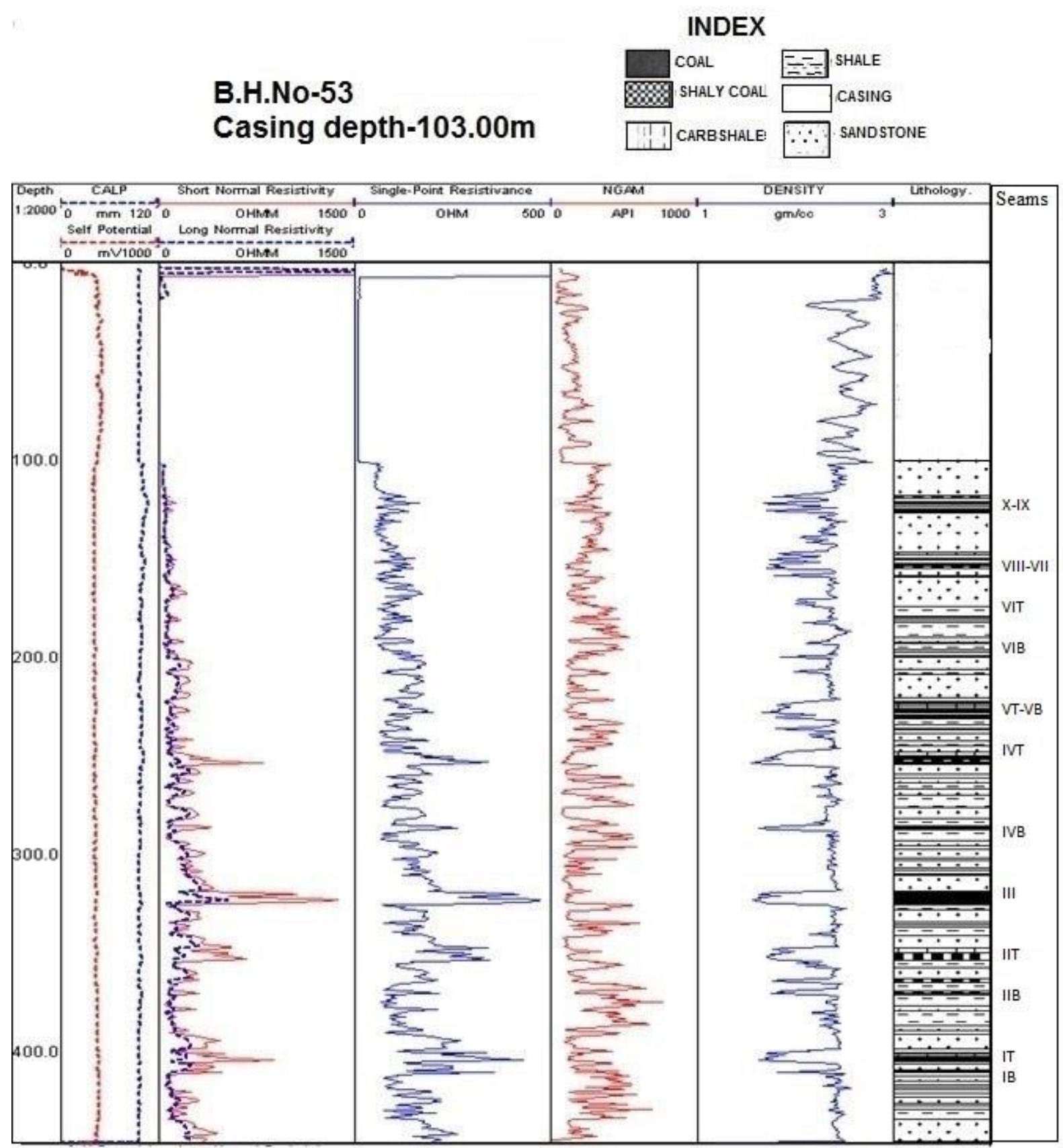


B.H.No-62

Casing depth-60.00m

\section{INDEX}

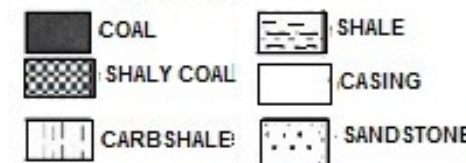

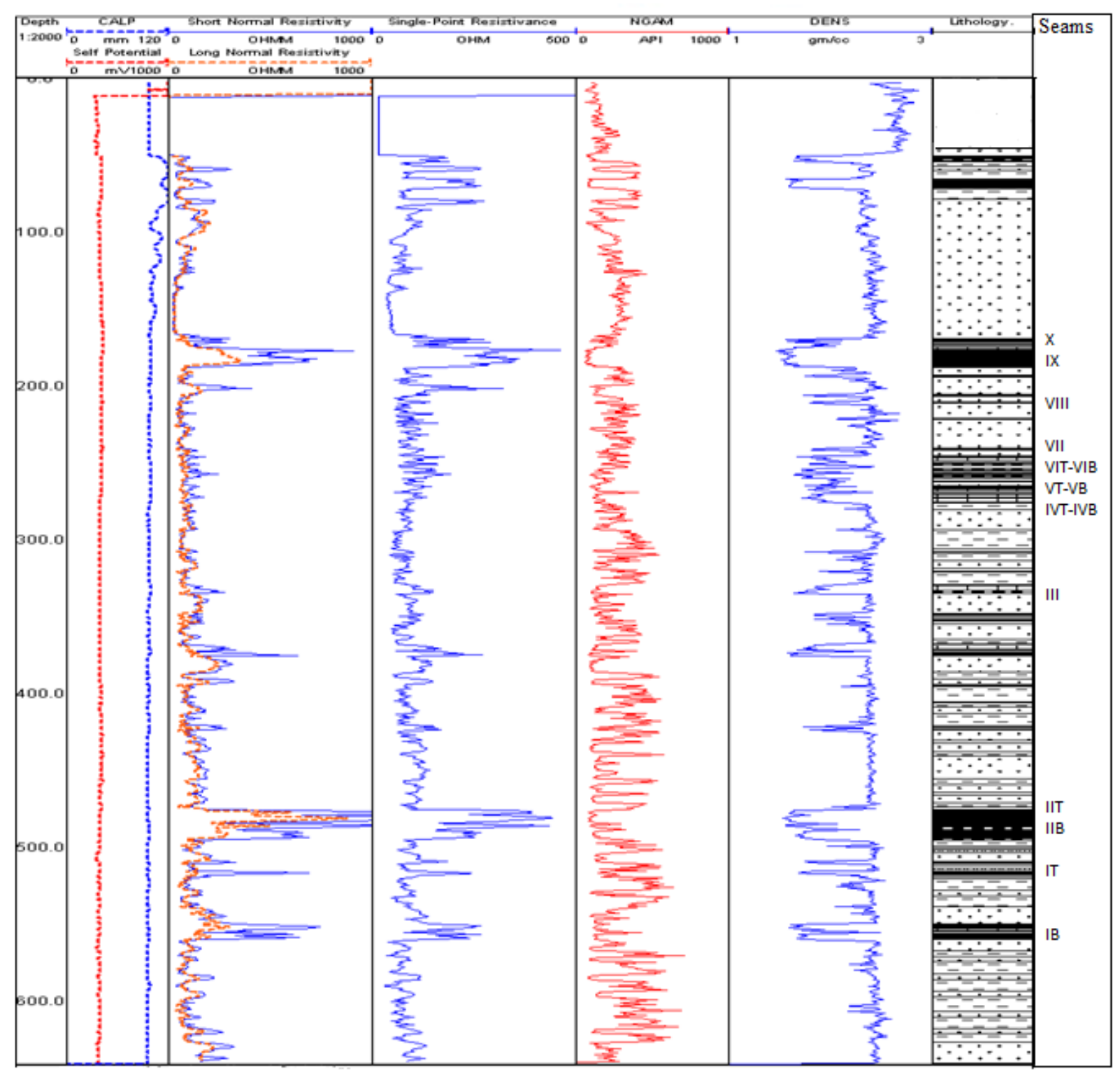




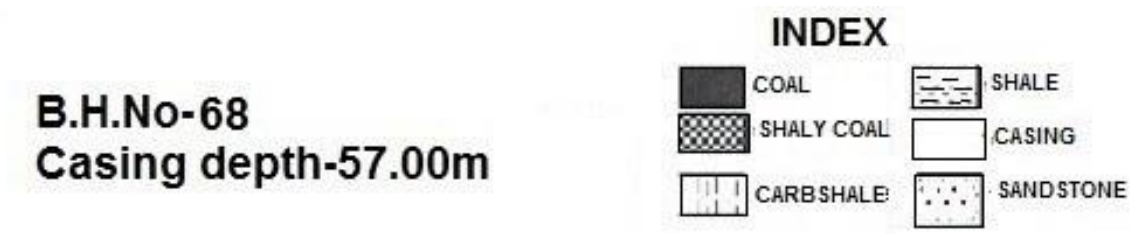

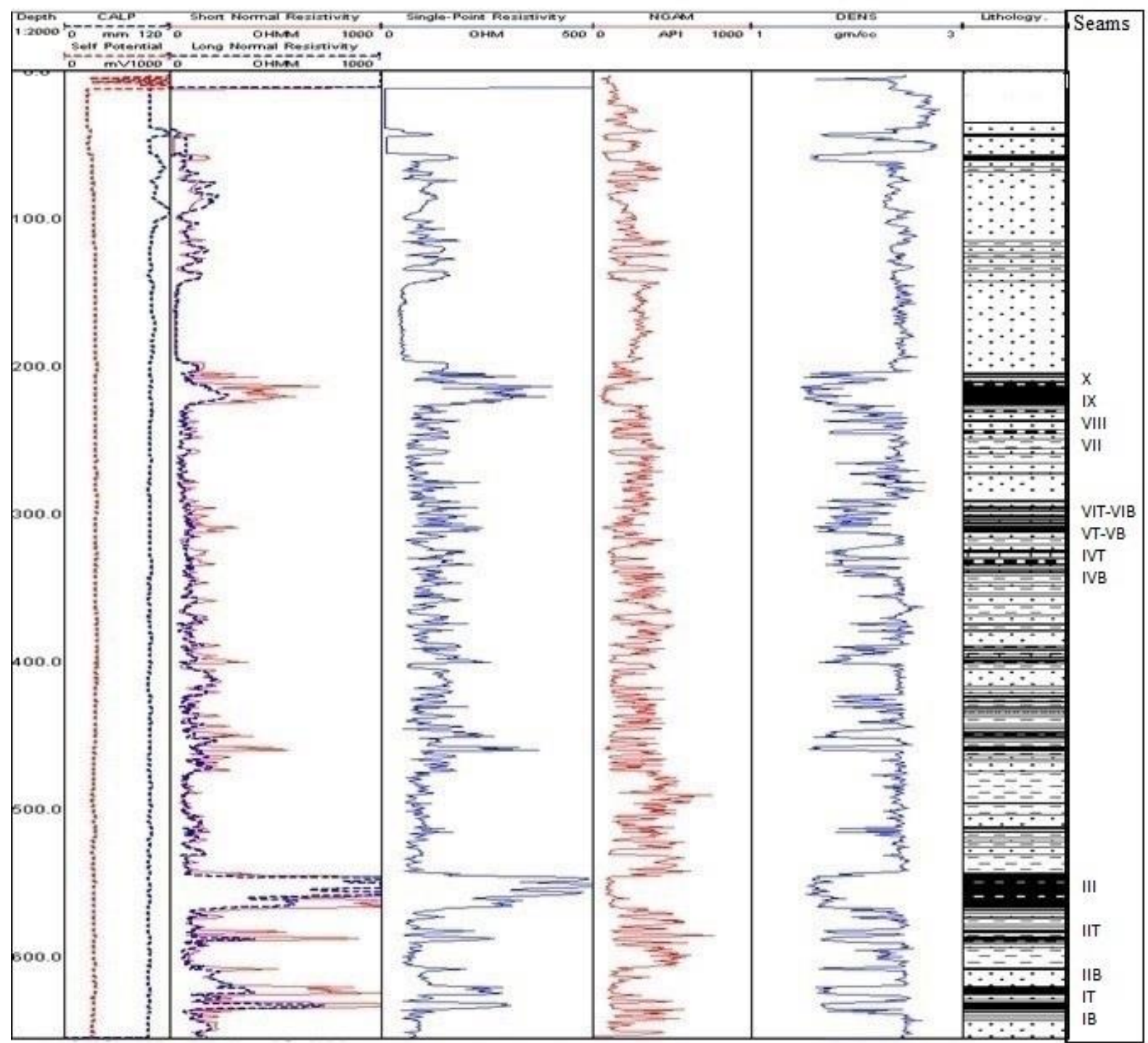




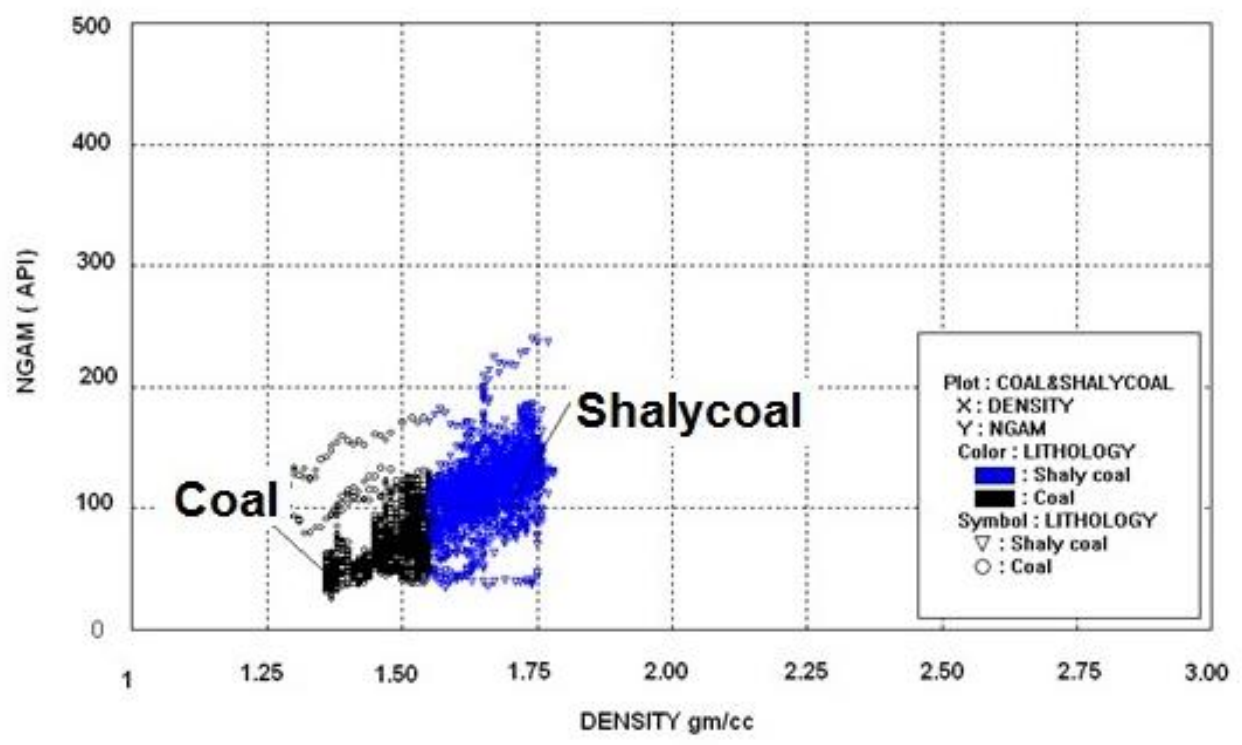

Fig. 12: The cross plots between Gamma-ray and density readings of shaly-coal and coal.

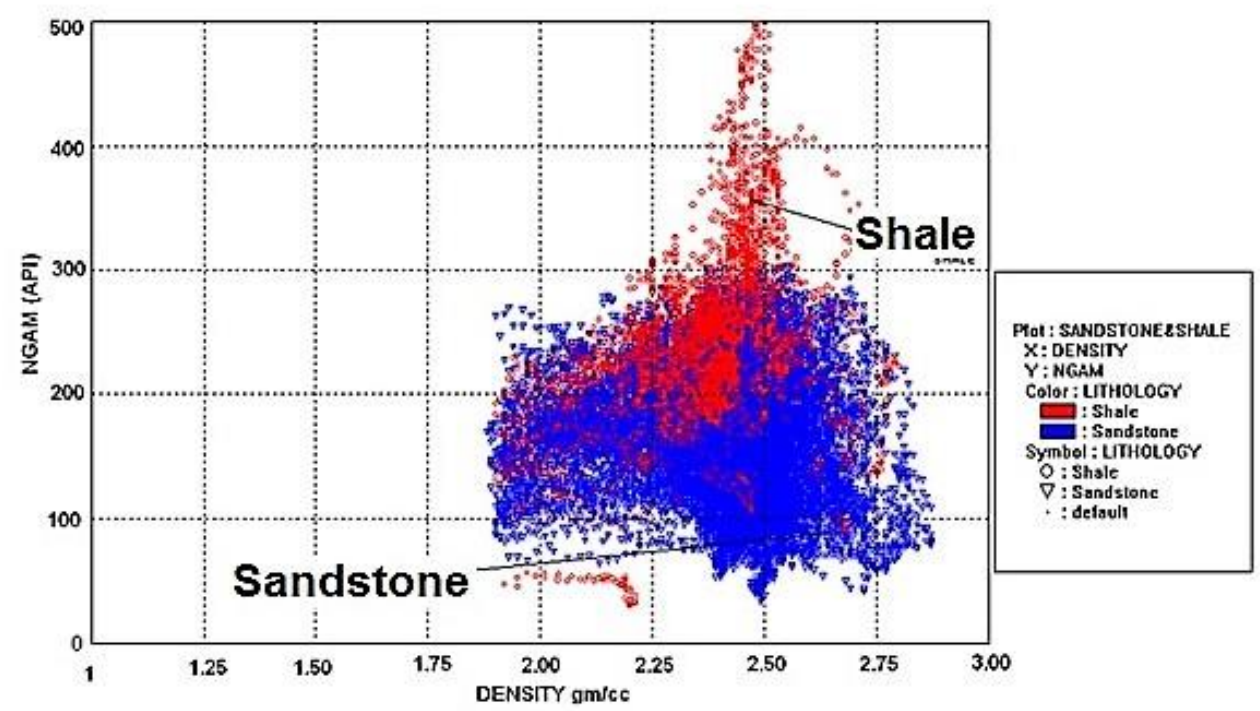

Fig. 13: The cross plots between Gamma-ray and density readings of sandstone and shale. 


\section{Tables}

Table 1. Generalized stratigraphic section of Auranga coalfield (Rao, 1987).

\begin{tabular}{|c|c|c|}
\hline Age & Formation & Lithology (thickness) \\
\hline Upper Triassic & Mahadeva & $\begin{array}{l}\text { Highly cross-bedded, medium to coarse- } \\
\text { grained-ferruginous sandstone, pebble } \\
\text { bed, and red shales. }\end{array}$ \\
\hline \multicolumn{3}{|c|}{ Unconformity } \\
\hline Lower Triassic & Panchet & $\begin{array}{l}\text { Medium to coarse-grained, feldspathic, } \\
\text { greenish to yellowish green purple } \\
\text { sandstones, with brown and chocolate } \\
\text { shales. }\end{array}$ \\
\hline Upper Permian & Raniganj & $\begin{array}{l}\text { Fine-grained Sandstone, shale, and } \\
\text { carbonaceous shale. }\end{array}$ \\
\hline Middle Permian & Barren measures & $\begin{array}{l}\text { Medium-grained Sandstone, shale and } \\
\text { carbonaceous shale. }\end{array}$ \\
\hline \multirow[t]{2}{*}{ Lower Permian } & Barakar & $\begin{array}{l}\text { Coarse-grained Sandstone, shale and coal } \\
\text { seams }\end{array}$ \\
\hline & Karharbari & $\begin{array}{l}\text { Coarse-grained Sandstone, shale and coal } \\
\text { seams }\end{array}$ \\
\hline Upper Carboniferous & Talchir & $\begin{array}{l}\text { Conglomerates, fine to medium grained } \\
\text { sandstone and olive green shale }\end{array}$ \\
\hline \multicolumn{3}{|c|}{ Unconformity } \\
\hline Precambrian & Metamorphic & $\begin{array}{c}\text { Granite gneiss, quartzite, amphibolite and } \\
\text { mica schists. }\end{array}$ \\
\hline
\end{tabular}


Table -2: Coal seams depth range and thickness in bore-hole- 28, 32, 36,37,45,46,53,62,68.

\begin{tabular}{|c|c|c|c|c|c|c|c|c|c|c|}
\hline Seam & $\begin{array}{l}\text { Depth } \\
\text { Range(m) }\end{array}$ & $\begin{array}{c}\text { BH.No- } \\
28\end{array}$ & $\begin{array}{c}\text { BH.No- } \\
32\end{array}$ & $\begin{array}{c}\text { BH.No- } \\
36\end{array}$ & $\begin{array}{c}\text { BH.No- } \\
37\end{array}$ & $\begin{array}{c}\text { BH.No- } \\
45\end{array}$ & $\begin{array}{c}\text { BH.No- } \\
46\end{array}$ & $\begin{array}{c}\text { BH.No- } \\
53\end{array}$ & $\begin{array}{c}\text { BH.No- } \\
62\end{array}$ & $\begin{array}{c}\text { BH.No- } \\
68\end{array}$ \\
\hline \multirow{3}{*}{$\mathrm{X}$} & From $(m)$ & 43.4 & 70.5 & 88.0 & 124.2 & 141.82 & 149.4 & 121.4 & 171.1 & 210.1 \\
\hline & $\mathrm{To}(\mathrm{m})$ & 57.2 & 78.3 & 89.5 & 125.3 & 157.7 & 151.1 & 122.6 & 188.0 & 220.1 \\
\hline & Thick(m) & 13.8 & 7.8 & 1.5 & 1.1 & 15.9 & 1.7 & 1.2 & 16.9 & 10.0 \\
\hline \multirow{3}{*}{ IX } & From(m) & 66.8 & 102.5 & 91.7 & 126.6 & 162.44 & 153.4 & 124.9 & 192.9 & 220.3 \\
\hline & To(m) & 68.1 & 104.1 & 93.7 & 127.8 & 164.20 & 155.8 & 126.7 & 194.4 & 226.2 \\
\hline & Thick(m) & 1.2 & 1.6 & 2.0 & 1.2 & 1.8 & 2.4 & 1.8 & 1.5 & 5.9 \\
\hline \multirow{3}{*}{ VIII } & From(m) & 68.7 & 107.2 & 127.5 & 129.0 & 168.5 & 158.4 & 152.3 & 210.4 & 229.4 \\
\hline & $\mathrm{To}(\mathrm{m})$ & 71.1 & 107.7 & 130.4 & 142.9 & 169.9 & 169.3 & 155.1 & 211.6 & 231.5 \\
\hline & Thick(m) & 2.3 & 0.5 & 2.9 & 13.9 & 1.4 & 10.9 & 2.8 & 1.2 & 2.1 \\
\hline \multirow{3}{*}{ VII } & From $(m)$ & 82.8 & 112.7 & 134.2 & 146.4 & 171.8 & 173.2 & 158.6 & 240.7 & 243.2 \\
\hline & To(m) & 84.0 & 118.0 & 137.5 & 147.5 & 173.8 & 174.9 & 159.3 & 241.9 & 245.6 \\
\hline & Thick(m) & 1.2 & 5.3 & 3.3 & 1.1 & 2.0 & 1.7 & 0.7 & 1.2 & 2.4 \\
\hline \multirow{3}{*}{ VIT } & From(m) & 95.4 & 121.9 & 138.4 & 150.3 & 186.0 & 179.2 & 223.5 & 246.0 & 290.5 \\
\hline & $\mathrm{To}(\mathrm{m})$ & 99.3 & 126.7 & 142.6 & 151.6 & 188.1 & 180.2 & 228.4 & 248.9 & 292.1 \\
\hline & Thick(m) & 3.9 & 4.8 & 4.3 & 1.3 & 2.1 & 1.0 & 4.9 & 2.9 & 1.6 \\
\hline \multirow{3}{*}{ VIB } & From $(m)$ & 104.7 & 127.5 & 144.6 & 153.0 & 224.5 & 182.0 & 229.7 & 250.6 & 295.2 \\
\hline & To $(\mathrm{m})$ & 106.4 & 128.7 & 146.4 & 155.8 & 225.2 & 184.7 & 231.6 & 251.9 & 298.2 \\
\hline & Thick(m) & 1.7 & 1.3 & 1.7 & 2.8 & 0.7 & 2.7 & 1.9 & 1.3 & 3.0 \\
\hline \multirow{3}{*}{ VT } & From(m) & 107.0 & 145.3 & 148.2 & 190.3 & 243.5 & 226.0 & 236.1 & 253.8 & 301.3 \\
\hline & To(m) & 110.1 & 146.7 & 150.1 & 193.1 & 250.8 & 227.1 & 236.9 & 256.0 & 302.6 \\
\hline & Thick(m) & 3.1 & 1.4 & 1.9 & 2.8 & 7.1 & 1.2 & 0.8 & 2.2 & 1.3 \\
\hline \multirow{3}{*}{ VB } & From(m) & 112.9 & 148.15 & 195.6 & 198.7 & 261.32 & 234.2 & 248.4 & 257.1 & 303.8 \\
\hline & $\mathrm{To}(\mathrm{m})$ & 114.8 & 149.25 & 196.4 & 202.5 & 268.8 & 236.4 & 254.6 & 260.1 & 307.0 \\
\hline & Thick(m) & 1.9 & 1.1 & 0.8 & 3.8 & 7.6 & 2.2 & 6.2 & 3.0 & 3.2 \\
\hline \multirow{3}{*}{ IVT } & From $(m)$ & 142.3 & 189.5 & 205.3 & 203.1 & 293.4 & 237.15 & 285.5 & 266.2 & 308.4 \\
\hline & To(m) & 144.4 & 194.7 & 211.5 & 217.7 & 297.0 & 245.7 & 287.5 & 268.5 & 312.5 \\
\hline & Thick(m) & 2.0 & 5.1 & 6.2 & 3.4 & 3.6 & 8.6 & 2.0 & 2.3 & 4.1 \\
\hline \multirow{3}{*}{ IVB } & From $(m)$ & 152.9 & 199.5 & 212.9 & 214.3 & 317.94 & 248.0 & 318.9 & 270.0 & 324.6 \\
\hline & $\mathrm{To}(\mathrm{m})$ & 159.7 & 201.1 & 213.7 & 217.7 & 324.4 & 252.5 & 325.4 & 276.3 & 329.1 \\
\hline & Thick(m) & 6.7 & 2.0 & 0.8 & 3.4 & 6.5 & 4.5 & 6.5 & 6.3 & 4.5 \\
\hline \multirow{3}{*}{ III } & From(m) & 174.8 & 202.2 & 230.7 & 275.6 & 348.9 & 315.6 & 347.4 & 329.9 & 543.3 \\
\hline & To(m) & 179.1 & 203.1 & 237.6 & 282.1 & 351.6 & 323.5 & 354.0 & 335.1 & 567.0 \\
\hline & Thick(m) & 4.2 & 1.0 & 6.9 & 6.5 & 2.7 & 7.8 & 6.6 & 5.2 & 23.7 \\
\hline \multirow{3}{*}{ IIT } & From $(m)$ & 189.1 & - & 262.3 & 307.4 & 370.0 & 345.3 & 363.3 & 475.9 & 582.0 \\
\hline & $\operatorname{To}(\mathrm{m})$ & 190.9 & - & 265.5 & 301.1 & 371.7 & 349.0 & 364.8 & 488.6 & 583.9 \\
\hline & Thick(m) & 1.8 & - & 3.1 & 2.7 & 1.8 & 3.7 & 1.5 & 12.6 & 1.9 \\
\hline \multirow{3}{*}{ IIB } & From(m) & 226.2 & 217.55 & 286.2 & 329.6 & 379.5 & 372.9 & 369.1 & 489.4 & 586.1 \\
\hline & $\mathrm{To}(\mathrm{m})$ & 229.3 & 220.15 & 287.6 & 332.7 & 382.6 & 375.5 & 371.1 & 495.3 & 590.0 \\
\hline & Thick(m) & 3.1 & 3.1 & 1.4 & 3.1 & 3.1 & 2.7 & 2.0 & 5.9 & 3.9 \\
\hline \multirow{3}{*}{ IT } & From $(\mathrm{m})$ & 280.3 & 221.45 & 314.0 & - & 401.7 & 457.5 & 400.5 & 550.1 & 619.8 \\
\hline & $\mathrm{To}(\mathrm{m})$ & 281.2 & 224.55 & 316.7 & - & 404.8 & 460.4 & 405.0 & 554.9 & 625.8 \\
\hline & Thick(m) & 0.9 & 3.1 & 2.6 & - & 3.1 & 2.9 & 4.5 & 4.8 & 6.0 \\
\hline \multirow{3}{*}{ IB } & From $(m)$ & 296.7 & - & 342.9 & 361.1 & 408.8 & 462.3 & 410.2 & 556.1 & 631.0 \\
\hline & To(m) & 298.7 & - & 346.2 & 364.0 & 410.7 & 464.1 & 410.9 & 560.1 & 635.5 \\
\hline & Thick(m) & 2.0 & - & 3.3 & 2.9 & 1.9 & 1.8 & 0.7 & 4.0 & 4.5 \\
\hline
\end{tabular}


Table-3: Characteristics of Geophysical well logs in the study area

\begin{tabular}{|c|c|c|c|}
\hline SI.NO & Formation & Natural Gamma (API) & $\begin{array}{c}\text { Density } \\
(\mathbf{g m} / \mathbf{c c})\end{array}$ \\
\hline & Barakar formation & & $2.0-2.80$ \\
\hline 2 & Sandstone & $50-400$ & $2.00-2.90$ \\
\hline 3 & Shale & $150-700$ & $1.40-1.55$ \\
\hline 4 & Coal & $34.00-108.00$ & $1.56-1.75$ \\
\hline 5 & Shaly coal & $39.00-220.00$ & $1.76-1.90$ \\
\hline
\end{tabular}

